\title{
Responding to affluence
}

Many commentators viewed Labour's failure to win the 1959 general election as evidence that, without fundamental change, the party could not prosper in what they described as the 'affluent society'. ${ }^{1}$ By 1966 , many of the same people believed Labour had been transformed and was largely in tune with contemporary developments. In accounting for this turn-about, most pointed to the impact of Harold Wilson, who became leader in February 1963. At Labour's annual conference in October that year, he tied his party's fortunes to the development of the 'scientific and technological revolution' and the promotion of 'the white heat of technological change'. Members drawn from across the party believed Wilson had given Labour a new vision for a new era. ${ }^{2}$

This chapter examines the development of Labour strategy between 1959 and 1966 and highlights the debate it provoked, as this revealed how members thought their party should best respond to change. Hugh Gaitskell and his successor assumed - just like many other contemporaries - that rising incomes had restructured society and that popular political attitudes had changed in step. As a consequence, they believed Labour had to reform itself, in particular how it communicated with key parts of the electorate: less stress was placed on the need to alter the party's organisation and policies. How far this approach contributed to Labour's 1964 and 1966 victories is moot. While it would be unwise to think the party played the most significant role in its electoral revival, it would be obtuse to imagine Labour contributed nothing at all.

\section{The 1959 campaign}

As with all such contests, it was only after the Conservatives won the 1959 general election that the result appeared inevitable. Armed with the belief that rising incomes were blurring class differences, such that better-off manual workers adhered to 'middle-class' values, many observers argued that the basic cause of Gaitskell's defeat was Labour's 
failure to come to terms with 'affluence'. Harold Macmillan's party won, in contrast, because it had responded with greater understanding. Authoritative sources predicted that if Labour did not react in like manner, it would probably never return to office. ${ }^{3}$ Having shared many of the assumptions of such analysts for a number of years, Gaitskell and his cohorts readily accepted their interpretation.

The result of the election had greatly disappointed Labour members, as it was the fourth time in a row the Conservatives had increased their share of the vote and the third in which their party's had declined. ${ }^{4}$ However, the extent to which Labour's defeat was the product of intractable and progressive social processes is, despite what was said afterwards, open to doubt. Certainly, before the election Gaitskell and many others in the leadership believed their party had more than a fair chance of winning. During the campaign, opinion polls indicated it was a close contest, so close in fact that the Conservatives feared the possibility of defeat. Even so, Macmillan was an assiduous operator, who invariably bested Gaitskell over tactics, and opinion polls showed that voters regarded him as the more effective of the two. Moreover, in the immediate run-up to the election the Conservative-inclined press had done its best to present Labour as divided over nuclear disarmament and nationalisation. Despite that, Labour's campaign was judged superior to the ruling party's, up to the point at which Gaitskell made what even sympathisers viewed as a serious blunder. He promised that taxes would not rise under a Labour government, as any extra spending would be financed through growth. This the Conservatives successfully presented as an irresponsible electoral bribe and Labour never recovered its momentum.

How important such matters were to the final outcome is questionable, as the contest was held during a period of general, sustained and unprecedented prosperity, which inevitably favoured the government. This was underlined by what was an exceptional two-year $£ 500,000$ Conservative advertising campaign, the basic message of which was, as one poster put it, 'Life's better under the Conservatives. Don't let Labour ruin it.' Instead of fighting on other ground, Labour compounded its disadvantage by concentrating its campaign on the economy, thereby encouraging voters to focus on an issue from which the government could only gain.

Insofar as Gallup's polling was accurate, some clear patterns emerge from the 1959 poll compared with that of 1955 and it is worth bearing these in mind (see Table 3.1). Labour lost support among uppermiddle-class, middle-class and even working-class voters but enjoyed considerably more backing from those categorised as 'very poor'. Among the youngest cohort of voters the party's position deteriorated, although it held on to most support among the middle-aged and actually improved 
Table 3.1 Labour's vote by social category, 1955-66

\begin{tabular}{lrrrr}
\hline & 1955 & 1959 & 1964 & 1966 \\
\hline Upper middle class & 9 & 6 & 9 & 8 \\
Middle class & 21 & 16 & 22 & 24 \\
Working class & 57 & 54 & 53 & 61 \\
Very poor & 54 & 68 & 59 & 72 \\
Men & 51 & 48 & 49 & 56 \\
Women & 42 & 43 & 39 & 48 \\
21-29 years & 54 & 47 & 47 & 56 \\
30-49 years & 48 & 47 & 45 & 53 \\
$50-64$ years & 42 & 40 & 40 & 53 \\
65 and above & 45 & 51 & 44 & 48 \\
\hline
\end{tabular}

Source: Gallup Poll, 'Voting behaviour in Britain, 1945-1974', in R. Rose (ed.), Studies in British Politics (1976), p. 206.

its popularity with the oldest voters. Labour also lost ground among men, while women electors showed a marginally greater inclination to support the party than previously - although far fewer still voted Labour compared with men.

The numerous post-mortems written by Labour's constituency agents, candidates and regional officials broadly agreed that their party had failed to appeal to enough younger, well-off workers. Husbands and working wives in their twenties - that is, the most affluent members of the working class - appeared especially resistant. ${ }^{5}$ It was, however, unclear how far the party's promise to increase nationalisation had created this situation, as Gaitskell was soon to claim. Reports from marginal seats in the East Midlands, for example, concurred that voters' prosperity went against the party. ${ }^{6}$ The agent in Bristol South East also painted a picture of Labour failing to win over young working-class couples enjoying a purchasing power beyond their parents' dreams. Ominously, he predicted that, 'short of an economic calamity', Labour was unlikely to increase support among such voters. ${ }^{7}$ In accounting for their party's victory, Conservative officials privately believed nationalisation was much less important than Gaitskell's tax pledge. ${ }^{8}$ Moreover, while Macmillan claimed the 'class war is over and we have won it', his party's officials were more cautious, appreciating that younger workers were unsteady Conservatives and so could not yet be counted firm supporters. ${ }^{9}$

Although it appeared to leave certain affluent voters unimpressed, Labour's campaign was hardly antediluvian. Through lack of money and inclination, the party did not use advertising to anything like the extent employed by the Conservatives. Still, it did try to reach voters in innovative ways, most especially with its pre-election statement The 
Future Labour Offers You (1958), which summarised Labour policy in an accessible and attractively illustrated manner. Commentators and voters alike thought the party's television broadcasts impressive - although some activists thought them 'a little too "clever". ${ }^{10}$ The national campaign directed from Transport House was, additionally, generally regarded as supremely professional.

The party's overall message was that its leaders were economically responsible, better able than the Conservatives to increase growth, and reflected the interests of the whole of society, while their opponents were concerned only for the rich. Promising to promote individual freedom, Labour believed this should not occur at the expense of wider social justice. Britain Belongs to You, its manifesto, stressed that Labour's socialist ethic meant 'none of us, however lucky or well-off we may happen to be, ought to feel comfortable in a society in which the old and sick are not decently cared for'. It pointed to the 'many millions' of 'havenots', and promised to raise pensions and improve provision for widows. Yet the manifesto also addressed the 'haves', and promised to extend personal liberty by setting up enquiries into betting restrictions, Sunday observance statutes and licensing laws. Labour's desire to enable people to take advantage of the opportunities created by full employment was more completely articulated in Leisure for Living (1959), issued some months before the campaign. This constituted an attempt to promote what Roy Jenkins described as 'gaiety, tolerance and beauty' and thereby extend party competition to areas beyond the economic. ${ }^{11}$

Labour tried to appeal specifically to the young as well, by promising to enhance their opportunities through creating a maintenance grant for sixth-formers and increasing it for university students, while improving access to education and training for those leaving school at fifteen years of age. It also pledged to improve leisure facilities for young people and promised that a Labour government would at least consider lowering the voting age from twenty-one.

Similarly, the party made numerous discrete appeals to women, largely - but not exclusively - on the basis of their domestic responsibilities. Thus, in a list of housewives' supposed 'Top Ten points of interest', one leaflet had, at number one, the 'house you live in', declaring it should be 'easy to run with modern amenities'. Number three was 'good health', and here the leaflet focused on pre- and post-natal care; numbers four and five also related to children, being 'education' and 'careers'. Six and seven referred to prices and consumer protection. Perhaps less conventionally, number eight - 'leisure' - asserted that the welfare state should give wives and mothers time to find paid employment or develop a hobby. Point nine stated that the party's pension plan would give housewives equality with wage earners..$^{12}$ Labour's main emphasis nonetheless fell on consumer issues. It promised to guarantee 
'value for money' by preventing monopolistic prices, ensuring the accurate labelling of goods and encouraging the activities of the Consumers' Association. ${ }^{13}$ This message was reflected in the party's television broadcasts. In one, the front-bench MP Eirene White claimed Labour's women MPs were especially concerned to keep down the cost of living, while, in contrast, the 'housewife's voice' was not heard on the Conservative side. Moreover, shown returning home with some shopping, White described herself as a 'working housewife' and sympathised with women trying to reconcile jobs with domestic duties, a message strikingly underlined by film of the redoubtable MP Bessie Braddock dressed in a pinafore wielding a Ewbank cleaner.

Labour's message was therefore a mix of appeals designed to maximise its vote among a variety of groups. It contained measures to maintain support among the 'traditional' working class while gesturing towards voters who had become more affluent. There were undoubtedly some at the top of the party, such as Morgan Phillips, the General Secretary, who believed unemployment 'marked the real difference' between the parties. ${ }^{14}$ Yet Labour's programme also addressed the concerns of those who took a well paid job for granted, rather than thinking it something for which they should be permanently grateful. Nonetheless, leading academic commentators believed that if the party was to stand any chance of ever again winning power, it had to abandon what they termed its 'schizophrenic image'. If Labour's manifesto had been a mixture of appeals, it was thought the party had to alter the balance and more explicitly win over the young and well-off. For, they believed, so far as Labour was concerned, the electoral consequences of social change meant things could only get worse. ${ }^{15}$ Thus, while Labour's national campaign had largely reflected their outlook, to Gaitskell and his closest lieutenants defeat meant the party should adhere ever more closely to their 'revisionism'.

\section{Accommodating affluence}

Although associated with Anthony Crosland's The Future of Socialism, first published in 1956, revisionism traced its immediate origins back to Evan Durbin's The Politics of Democratic Socialism (1940), which was written in the late 1930s, when Britain still experienced mass unemployment. Crosland gave this perspective a more contemporary gloss although even his thinking was clarified during post-war austerity. In 1950 he had claimed that capitalism was evolving into a new economic configuration, one that mitigated the worst excesses of the unbridled free market. ${ }^{16}$ While not socialism, this new order produced ineluctable growth and attenuated class conflict by improving incomes and increasing 
the size of those 'intermediate classes' who were neither manual workers nor employers. This new system resolved what Karl Marx supposed were capitalism's inherent contradictions and was capable of delivering continued rising living standards to the working class. As a result, the worst injustices and miseries associated with capitalism were on the verge of abolition. Yet, while making life better, what Crosland termed 'Progressive Capitalism' could never eliminate class distinctions and would not evolve into socialism without further political pressure. Socialism was therefore still necessary but might take several generations to come about - and in order to win power Labour had to make a special appeal to the 'intermediate classes', as they would in future determine the outcome of elections.

In 1951 a Socialist Commentary editorial elaborated on Crosland's view and outlined what would become party strategy under Gaitskell and Wilson. This stipulated that if Labour was to regain power, it had to win over the 'floating vote', which meant standing on the centre ground. The 'glaring grievances of the past' had been 'eliminated' and while 'no one pretends that the whole job has been done', poverty was much diminished and a substantial redistribution of income had taken place: Britain was experiencing 'at least the beginnings of an egalitarian society'. This meant Labour had to 'look beyond the old gospel of more and more nationalisation, "workers' control" or class appeals to "soak the rich"'. ${ }^{17}$ Gaitskell's response to the party's 1955 defeat reflected this perspective and anticipated his attitude to the 1959 loss. Hence he believed unprecedented access to ' $\mathrm{TV}$, new gadgets like refrigerators and washing machines, the glossy magazines with their special appeal to women and even the flood of new cars on the home markets' meant 'more and more people are beginning to turn to their own personal affairs and to concentrate on their own material advance'. It was, he advised members, 'no good moaning about it'; policy should be made to fit in with this new individualism and presented in terms sympathetic to it. ${ }^{18}$ After becoming leader in 1955, Gaitskell consequently did his best to dilute Labour's close connection with state ownership and ensured it went into the 1959 campaign committed only to renationalising steel and long-distance road haulage companies.

The revisionists were determined, as Jenkins put it, to 'use this shock' generated by defeat to promote Labour's further transformation. ${ }^{19}$ Thus, Gaitskell or those closest to him: demanded that the party recast its links with the unions; called for a rethink about its relationship with the Liberals; and suggested Labour should change its name. Gaitskell's own preoccupation, however, was with nationalisation, specifically clause four of the party's constitution, which associated Labour with a seemingly unqualified aspiration to increase public ownership. Although he considered it irrelevant to policy-making, Gaitskell believed the clause 
distorted affluent voters' perception of his party because it allowed the Conservatives to claim Labour wanted to nationalise everything. Revising the clause would, he thought, more accurately reflect Labour's purpose and thereby make the party seem more relevant to modern Britain.

This analysis underscored Gaitskell's contribution to the debate on the election held at Labour's 1959 conference. ${ }^{20}$ The fundamental cause of defeat, he argued, was the transformation of capitalism, to which Labour had to fully adapt. This meant members needed to accept that most workers were well off and free of the fear of unemployment. They also had to appreciate that the party could no longer rely on manual workers' 'instinctive loyalty' to secure power. White-collar employees would, he predicted, eventually outnumber the proletariat, who, in turn, would be transformed, such that the 'typical worker of the future' would be a 'skilled man in a white overall, watching dials in a bright new modern factory [rather] than a badly paid cotton operative working in a dark and obsolete 19th-century mill'. Owing to the 'particularly notable increase in comforts, pleasures and conveniences' in the home, women's lives were, Gaitskell stated, now 'a good deal easier'. Yet, owning washing machines, refrigerators and the like made them even less likely to vote Labour than in the past. It was, he warned, no use 'dismissing the problem, as some do, by saying that women are too snobbish or too politically apathetic': they were, Gaitskell declared, 'voters and count just as much as men'. In order for Labour to improve its appeal, he told delegates, the party should revise its aims.

While not dissenting from his analysis, members of Gaitskell's shadow Cabinet, along with those at the top of the Transport House bureaucracy, thought it foolish to try to change clause four. ${ }^{21}$ Most believed it less electorally significant than their leader and feared the process of revision would expose divisions in the party, for activist members thought the promotion of public ownership inherent to the party's basic purpose and looked on clause four as a guarantor of its commitment to socialism. ${ }^{22}$ The year 1959 was in fact the first to see the clause printed on the back of membership cards, which was the result of a campaign by activists in Newcastle upon Tyne who were concerned by the leader's lack of enthusiasm for nationalisation. ${ }^{23}$ This sentiment was, in contrast, less obvious among the party's wider membership: indeed, at the height of the controversy, 54 per cent of those in the Newcastle-under-Lyme party claimed never to have heard of clause four. ${ }^{24}$

Gaitskell lacked sufficient support among trade union representatives on the National Executive Committee (NEC) for revision, although he was allowed to add a statement of aims that could sit side by side with the clause. This additional statement claimed Labour's 'central ideal' was 'the brotherhood of man', which meant it rejected 'discrimination on grounds of race, colour or creed' and held 'men should accord 
to one another equal consideration and status in recognition of the fundamental dignity of man'. As it stood for 'social justice', Labour also sought a 'classless society', in which the 'wealth produced by all is fairly shared among all', where 'differences in rewards depend not upon birth or inheritance but on the effort, skill and creative energy contributed to the common good' and where 'equal opportunities exist for all to live a full and varied life'. The party also embraced 'democracy in industry, and ... the right of the workers both in the public and private sectors to full consultation in all the vital decisions of management, especially those affecting conditions of work'. It, moreover, remained convinced that these objectives could be achieved only through 'an expansion of common ownership substantial enough to give the community power over the commanding heights of the economy' although private enterprise had a legitimate place in the economy and nationalisation would be applied only 'according to circumstances'. Finally, Labour stood for 'the happiness and freedom of the individual against the glorification of the state' and 'any exercise of arbitrary power' ${ }^{25}$ Few in the party were impressed with these additional aims: Bradford East's general management committee (GMC) considered them an 'unnecessary and meaningless conglomeration of words', while Frank Cousins, left-wing leader of the Transport and General Workers' Union, believed they meant 'all things to all people'. ${ }^{26}$

\section{Criticising affluence}

After his leader's rebuff over clause four, Crosland wanted to reduce the influence of the left by expelling about twenty MPs from the Parliamentary Labour Party, including those, such as Michael Foot, he termed 'Tribune extremists'. The left needed to be reined in, Crosland figured, because they prevented Gaitskell taking full account of the electorate's new mood by forcing him into compromises that blurred the necessary message. ${ }^{27}$ Unfortunately for Crosland, more than a few rebellious MPs stood between Labour and what he considered the correct reaction to defeat. Many of the left's misgivings about 'affluence' were widely shared, even by some normally defined as revisionists.

For most party members, 'affluence' was neither expected nor welcome. Labour entered opposition in 1951 believing it had won a moral victory because Clement Attlee had gained more votes - if fewer seats than Winston Churchill. Members generally believed the outgoing government had applied policies that were both correct, in terms of moving the country closer to socialism, and popular. To them, it was self-evident that the state was superior to the market and that collective provision was more effective than any system dependent on individual resources. ${ }^{28}$ 
Few considered there was any need to adapt the programme first outlined in 1945. As one Labour journal published in Essex put it, after a brief hiatus, the people would:

return to the Socialist planning now interrupted, which has saved and revived this country, and will turn again with relief to the policy of social justice which is implicit in Labour's principles, and of which Toryism knows nothing.... This Tory night can only be brief ... they cannot reverse the march of social progress. With the first light of dawn, they and their misdeeds will vanish. ${ }^{29}$

Activists expected the Conservatives, in attempting to reverse "progress', would attack living standards and raise unemployment. In the face of much contrary evidence, that is what many claimed to see. In 1953, for example, members across the country were informed that the return of the 'hungry' thirties was imminent. ${ }^{30}$ At the 1955 election, some candidates claimed the Conservatives had caused real wages to fall and inequality to increase. ${ }^{31}$ In 1957 , Judith Hart similarly drew the attention of her selection meeting in Lanark to the apparent fact that poverty was 'striking again at the underprivileged' owing to the impact of conscious Conservative strategy. ${ }^{32}$ At the time of the 1959 contest, a number claimed inter-war conditions were returning to some parts of the country. ${ }^{33}$

Even members who accepted the reality of 'affluence' and believed the party needed to adapt were often critical of its wider impact. One of Gaitskell's own additional aims asserted that, as the 'pursuit of material wealth by and for itself' was 'empty and barren', the party rejected the 'selfish, acquisitive doctrines of capitalism' and strove to create a 'socialist community based on fellowship, co-operation and service'. As one of Labour's few teenage activists had it, affluence caused the people to lose their sense of purpose: they were 'working all day for money and then making their main hobby gambling for more' because they were wallowing in an ignorance induced by bingo, fashion and pop music. ${ }^{34}$ It was this crude materialism that offended those like the MP Reginald Sorenson, who feared the 'feverish obsession with competition for private gain' threatened to submerge those 'deeper values', based on 'communal service and co-operation', that Labour cherished. ${ }^{35}$ It was for this reason the revisionist Douglas Jay led the campaign to prevent the introduction of independent television during the early 1950s; after its authorisation by Act of parliament in 1954, the loyalist MP George Rogers deprecated it as further strengthening the 'corrupting influence of commercialism'. ${ }^{36}$ Later in the decade, many opposed the introduction of Premium Bonds on the same basis. ${ }^{37}$

Some held those who rose up the social ladder during this period in withering contempt. A Labour veteran from Wapping noted that affluence 
enabled former residents to move to the suburbs and buy cars, television and radios. This new-found individual security had, however, caused them to abandon the pursuit of 'disinterested public service'. ${ }^{38}$ Writing in the late 1960s, the left-wing MP Leah Manning recalled canvassing in Chingford during the 1950 campaign, where she noted early signs of 'a phenomenon which is part of our changing society': having moved to a more middle-class district, voters born into the working class had apparently changed their party affiliation. 'One can only admire', she conceded, 'their anxiety to do better for their children and obtain the amenities which make their homes and lives more comfortable'. Manning, nonetheless, doubted they had changed party through conviction and believed it was merely 'an outward and visible sign of that inward grace which had transferred them into "middle class" respectability'. ${ }^{39}$ Others were less patronising but equally disappointed by evidence of such aspirations: when a meeting of Bedford's GMC was informed that a majority of council tenants wanted to own their home, those present let out audible sighs of dismay. ${ }^{40}$

Like their revisionist counterparts, the left had a ready-made explanation for defeat in 1959, one prefigured in debates conducted at least as far back as the late 1940s. Indeed, many believed matters had gone awry when the Attlee government refused to nationalise even more of the private sector than was promised in 1945. ${ }^{41}$ The MP Geoffrey Bing accepted that the Conservatives returned to office in 1951 on the back of support from a significant minority of the working class. His solution was, however, the reverse of that proposed by Socialist Commentary: Bing thought Labour would win back proletarian Tories if Labour advocated a 'clear, simple Socialist policy' of drastically extending public ownership. ${ }^{42}$ The ex-MP John Freeman later argued that, if Labour chased middle-class voters by watering down its commitment to state control, it would not only fail but would also alienate working-class supporters. ${ }^{43}$ Thus, Cousins was not alone in believing that what one activist described as the leadership's 'wishy-washy thinking' had prevented up to six million 'Socialists in embryo' from supporting the party in 1959. ${ }^{44}$ As Aneurin Bevan's Ebbw Vale constituency Labour party (CLP) advised the ailing Daily Herald, the paper - just like Labour - would revive its popularity if it decided to 'rededicate itself to a socialist policy, divesting itself of the idea that we can make capitalism work better than the establishment' ${ }^{45}$

What Crosland thought a permanently reformed capitalism, the left took to be a 'halfway house that cannot endure', which would inevitably usher back mass unemployment. ${ }^{46}$ Revisionists tended to look to the United States for clues to Britain's future and saw merit in emulating at least some aspects of American society. ${ }^{47}$ On the left, only economies dominated by state ownership were thought worthy of study, for they 
alone had permanently freed themselves of the threat of unemployment. As Labour's candidate in Folkestone told activists in 1959, collective ownership was the reason why the Soviet Union had achieved unknown levels of prosperity and equality and had outstripped the United States in economic performance. ${ }^{48}$ Edinburgh Fabians were informed by one of their number that too much was made of the drabness of life in the Soviet Union. The people now dressed in colourful fashions and, while their styles were not too modern, the material was more than adequate. Moreover, consumer goods were in ample supply and generally of the same quality evident in Britain. Furthermore, and possibly for a Fabian audience more importantly, workers were tidier and more civil than their British counterparts. ${ }^{49}$ Thus, as affluence would inevitably give way to depression, Labour should remain what the MP Richard Crossman described as a 'Fighting Socialist Opposition', unsullied by compromise. ${ }^{50}$

If accommodating the needs of a transient affluence was thought unwise, many also considered it unscrupulous. The Conservatives won in 1959 because they had appealed to what one Basingstoke activist said was 'Snobbery, Selfishness and Fear'. If Labour emulated its rival, the party would betray socialism. ${ }^{51}$ As Foot had it, "we have to change the mood of the people of this country, to open their eyes to what an evil and disgraceful and rotten society it is'. ${ }^{52}$ One self-consciously 'oldfashioned Socialist' active in Falmouth argued that Labour's purpose was to 'liberate the people from this TV-Bingo pseudo-culture, and in its place make the people of this country feel that life can be a grand adventure, and give them a horizon that they never thought possible'. ${ }^{53}$ The secretary of Warwick and Leamington Spa CLP also argued that Labour should persuade voters that socialism was a 'way of life that can lead to a better understanding between man and man, nation and nation; that it is an alternative to the way that glorifies the money lender and the gambler, that it can lead to a better life for all'. ${ }^{54}$ Thus, Mary Sutherland, Labour's Chief Woman Officer, considered that rather than change policy, the party should 'think hard about how to improve our methods of educating the electors' ${ }^{55}$ In particular, Labour's task was, the agent in Bristol Central believed, to alert affluent voters unconcerned about the plight of 'those less well off, either the older folk in their own country or the underprivileged overseas', to their 'responsibilities' ${ }^{56}$

It was not, therefore, Labour's job to change itself, but to reform society in its own image. As it was believed workers voted Conservative owing to the deliberate manipulation of their most irrational impulses, just because the party lost votes did not mean it was wrong. ${ }^{57}$ A delegate at the 1959 Labour Party annual conference forcefully advanced this perspective by declaring how appalled he was that so many speakers proposed 'appeasing public opinion'. Instead, he suggested: 
Let us show we are basically a moral Party, who believe in truth and believe in socialism! If we do that, it does not matter whether we become a Government in 1964, 1974 or 1984 . When we do form a government, I know that we have something to offer the country. We have a new world to offer them, and a new society, not a botched-up old system. Let us go forward from this Conference! Let us go forward and not turn back $!^{58}$

Many believed this approach would work. MPs like Coventry's Maurice Edelman, a long-time left-winger, believed their own constituency victories derived from 'our advocacy of an uncompromising Socialism with nationalisation' ${ }^{59}$ If Gaitskell wanted to win national office, he should adopt a similar strategy.

\section{Focus on image}

Crosland opposed his leader's attempt to alter clause four because he thought Labour could transform its fortunes without substantially changing principles or policies. Instead, he thought the main task should be to reshape its 'image'. ${ }^{60}$ As the West Leeds MP and Gaitskell loyalist Charles Pannell suggested, Labour lost in 1959 mainly because it had not resonated with affluent voters 'kidded' by the Conservatives' posters. ${ }^{61}$ This interpretation was also favoured at Transport House, where Phillips was keen to avoid a divisive debate about policy and ideology. ${ }^{62}$

Crosland had long considered that 'intermediate' groups, such as white-collar workers, were politically unstable because of the tension he detected between their incomes, often no more than those of skilled manual workers, and their conviction that they belonged to a superior class. This contradiction between objective and subjective position meant non-manual workers were, Crosland thought, fated to 'float' between the two essentially class-based parties. Moreover, as he believed rising incomes had reduced class differences, Crosland thought voters as a whole were less inclined to make 'automatic' assessments of their interests than hitherto. Instead, they were more 'pragmatic' in their judgements and so amenable to 'rational persuasion'. This meant Labour should concentrate on how it presented 'itself and its policies to the public, to the tone and content of its propaganda, and generally to the impression which it makes on the voters'. Labour also needed to abandon the 'sectional, traditional class appeal', which Crosland considered still dominated the 1959 campaign, and to portray itself as 'a progressive, national, social-democratic party'. As others suggested, Labour should develop an all-embracing image, one that appealed to the interests of both 'haves' and 'have-nots'. ${ }^{63}$ 
After failing to revise clause four, Gaitskell and his advisers fully endorsed this perspective, considering the best way to project Labour's image was through an advertising campaign based on research into voter attitudes similar to the one undertaken by the Conservatives. They believed there was no other way of reaching affluent voters, as they were unlikely to attend public meetings, preferring as they apparently did to stay at home watching television. As they were also deemed to have no interest in the minutiae of political debate, these electors were thought likely to be swayed by comparatively unimportant, non-intellectual influences. Hence the right image was critical to advancing Labour's fortunes.

Employing techniques associated with advertising proved not much less controversial than trying to revise clause four. Some Labour members viewed them as immoral, owing to their association with the Conservative enemy. Given that one of the least savoury aspects of affluence was considered to be the burgeoning of advertising, others were queasy about using the same methods to promote their party. ${ }^{64}$ As one agent declaimed: 'Ad men are no more interested in the Labour Party than they are in my Aunt Fanny ... all they know about is appealing to people's greed, whereas we are trying to appeal to their ideals' ${ }^{65}$ Others, including the National Agent, thought Labour could recover its position through better organisation; to his mind, advertising would just waste precious funds. ${ }^{66}$

\section{Opening up the organisation}

Given the leadership's emphasis on advertising, one constituency agent claimed a growing number of activists were 'beginning to wonder if some of our more traditional activities are not just a sheer waste of time and energy'. ${ }^{67}$ Yet even the most enthusiastic advocates of advertising, such as the pollster Mark Abrams, believed members could still help by opening up their parties to uncommitted groups of voters. ${ }^{68}$ As subsequent chapters focus on attempts to attract women, black immigrants and the young, this section concentrates on initiatives to increase the participation of 'intermediate' voters. In his analysis of Labour's problems, Phillips laid great stress on the fact that Labour was ceasing to be a 'mirror of the nation at work', owing to the relative lack of nonmanual workers in its ranks. ${ }^{69}$ This imperative dominated after 1959 and was underlined by the spectacular Liberal 1962 by-election victory in the Conservative stronghold of Orpington, which suggested that even suburban voters disenchanted with Macmillan's government were resistant to Labour's charms. ${ }^{70}$

To encourage activists to help change Labour's image, and make local parties more attractive to non-manual workers, a national competition 
was established in 1961 to improve the appearance of constituency offices. Members were asked whether passers-by would, 'from looking at YOUR premises, get the idea that Labour is finished, down at heel, out of date, or do they get an impression of a modern forward looking Party, clean, efficient and belonging to the space age?"71 Officials urged activists to hold special meetings for doctors, teachers and managers in what they supposed would be amenable surroundings, like hotels, where cocktails might be served. ${ }^{72}$ Opposition to these proposals was not necessarily due to politics: left-wingers were not averse to attracting middle-class supporters so long as this was not accompanied by any watering down of policy. ${ }^{73}$ Some hostility, though, was due to cultural prejudice, so that in the eyes of one agent, 'petty bourgeois wine bibbing' appeared 'a load of gimmick-dressed tripe'. ${ }^{74}$

Officials initially hoped the unions would help them attract more white-collar members. Yet discussions held in Transport House during 1961 with eleven non-manual workers' unions affiliated to the party were inconclusive: few were prepared to make a special effort. ${ }^{75}$ In light of that, Labour would have to approach such workers not as trade unionists but as individual voters. ${ }^{76}$ One possible means was revealed during Tony Benn's campaign to remain an MP after being forcibly elevated to the Lords after the death in 1960 of his father, who happened to be a hereditary peer. This saw Labour in his Bristol South East constituency tap into support normally beyond its reach and raised questions in Benn's mind about how Labour nationally could attract 'progressive' members of the middle class. ${ }^{77}$ Benn and others believed the Bristol experience - as well as that of the Democrats in the United States - showed the advantages of establishing a more flexible organisation he called 'Citizens for Labour'. He hoped to create the category of 'associate member', which would allow individuals to avoid being a full party member but would encourage them to donate their cash and help at election time.

Considering his own CLP 'effectively dead', Benn believed his scheme would help create 'a more or less new Party which can somehow be latched on to the old one'. ${ }^{78}$ While a party on the left - which in 1960 called for Gaitskell's resignation - Bristol South East was run by a small aged coterie of about fifteen activists whose secretary had been in the party since 1918. GMC meetings rarely involved policy debates unless Benn was present, which, as a busy MP with wider responsibilities within the national Labour Party, he rarely was. When it was suggested they should have speakers to promote discussions the proposal was rejected ostensibly because, as so few attended GMC meetings, it was not worth the effort. ${ }^{79}$

Benn's scheme required the permission of the NEC. Despite the fact that in 1929 the NEC had proposed a similar scheme, members of the 
Organisation Sub-committee (OSC) thought it dangerously novel and, after what Benn described as an 'appalling row', refused to endorse it. ${ }^{80}$ The majority felt associate membership would leave Labour's basic problems untouched, as it would not challenge the control of 'small cliques of full members', who dominated too many local parties. Instead, Labour needed to bring new groups into full membership so they could change the organisation from within. In fact, the OSC mainly reproduced objections to a not dissimilar proposal aired in the wake of Labour's 1955 defeat. ${ }^{81}$ Undeterred, Benn put his case to the Sub-committee again. Despite the shadow Cabinet minister Ray Gunter warning of its 'subversive' potential, this time the NEC allowed Benn to launch Citizens for Labour, although only on an experimental basis in Bristol South East. ${ }^{82}$ Transport House officials remained doubtful. Sara Barker, the National Agent, thought there were too few activists to develop such informal arrangements: above all else, Labour needed more active members. ${ }^{83}$

Few in Benn's local party believed in the scheme. While endorsing Citizens for Labour in the MP's presence, the GMC was unwilling to take it seriously in his absence. From the start some believed they should oppose 'anything out-of-line with general thinking'. Unfortunately for Benn, the NEC stipulated the CLP had to form a sub-committee drawn from GMC members to supervise the initiative, so it remained firmly under activists' control. ${ }^{84}$ It was therefore no surprise that it made little impression. Local activists also opposed Benn's other initiative of this period, the New Bristol Group, which was again founded in the wake of his campaign to stay in the Commons. The aim of this body was to bring together those the MP termed 'thoughtful people' to stimulate debate about the city's problems. The extent to which his GMC looked with disfavour on the Group was reflected in its endorsement of the city council's decision to prevent libraries stocking its publications. ${ }^{85}$

\section{'Let's Go!'}

Attempts to make CLPs more attractive to non-manual workers largely foundered, but more headway was made centrally in improving the party's image. In 1961 the NEC established the Campaign Sub-committee to take command of the party's election preparations. ${ }^{86}$ This took note of surveys conducted by Abrams, all of which underlined the importance of projecting Labour as a 'classless' organisation that was representative of the interests of the entire working population. The main result of this work was a $£ 100,000$ advertising campaign, which ran during the second half of 1963, the main purpose of which was to convince affluent voters that Labour could improve their standards of living. Its basic message was summed up in the first press advertisement, which comprised 
a large picture of the Labour leader and a brief explanation of the party's case, under the legend, 'Harold Wilson explains Labour's New Plans for making Britain Dynamic and Prosperous Again' ${ }^{87}$

As affluent voters were supposed to decide how to vote on the basis of 'impressions and instincts', it was 'their idea of what kind of party' Labour was that mattered. Thus, the campaign was thought to require a phrase and symbol to encapsulate what Labour stood for. After some debate, a supposedly cheerful thumbs-up sign accompanied by the slogan 'Let's Go with Labour and we'll get things done' became the favoured devices. Some found them distasteful. When the 'Let's Go' campaign was launched, Pannell confided to his Leeds members, 'I am afraid we will have to do it that way' to win over the 'soft south', that is, inhabitants of 'rootless constituencies - those places without collective memory which have sprung up over night with no long civic tradition' ${ }^{88}$ Even worse, from Pannell's perspective, Transport House encouraged Labour mothers to put 'Let's Go' badges on their children; there was also 'Let's Go' window posters, envelope and car stickers - in Doncaster activists even held a 'Let's Go' balloon race. ${ }^{89}$

Wilson's reference to 'white heat' during his 1963 conference speech was designed to complement this work. Although his emphasis on the 'scientific revolution' appeared to distinguish the Labour leader from his late predecessor, others had called for the party to associate itself with science some years before. ${ }^{90}$ If any one person was responsible for Labour's invocation of science, it was Morgan Phillips - although he owed much to the unacknowledged help of Richard Crossman and Peter Shore. ${ }^{91}$ Phillips initially hoped science would draw members away from their disagreements over clause four - only later on did it appear an important means of signifying the party's modernity. ${ }^{92}$ With these objects in mind, in July 1960 Phillips presented to the NEC a document entitled 'The state of the party', which: was subsequently expanded and given the more optimistic title of 'The future of the party'; eventually became Labour in the Sixties; was elaborated into the pamphlet series Signposts for the Sixties; and finally formed the basis for Labour's 1964 manifesto.

The NEC commended Labour in the Sixties to the 1960 conference, although it did not, as was customary with such documents, endorse it. Instead, it was designated as 'the work of the General Secretary', an unusual formula, the result of Gaitskellites and their left-wing opponents being initially unable to agree on its merits. ${ }^{93}$ Introducing it, on behalf of an ill Phillips, Ray Gunter told delegates that its intention was to 'project our thoughts away' from internal disputes. In anticipation of Wilson's speech three years later, he affirmed that 'never in history have Socialist principles been more relevant than they are in the 60s', owing to the need for the state to direct scientific developments. Wilson in fact 
closed the debate by hoping the document marked the end of 'sterile' arguments over nationalisation and would help Labour face the future rather than dwell on the past. ${ }^{94}$ If most on the left saw it as marking a welcome move from revisionism, at least one conference delegate, from Toxteth, considered the document so 'obviously intended to attract middleclass votes' that it should be renamed Signposts for the Right..$^{95}$

What the leadership hoped would be a reforging of Labour's image went hand in hand with the projection of Wilson, for the successful dramatisation of Macmillan's supposed traits was thought to have been one of the reasons for the Conservative 1959 victory. So far as affluent voters went, Labour's image needed personification and this was obviously to be achieved through the leader. ${ }^{96}$ In this process even Michael Foot played a part, penning a hagiography of Wilson during the runup to the 1964 campaign. These efforts were undoubtedly helped by the fact that, by 1963, Macmillan was widely regarded as 'old, effete, worn out'. Labour strategists could not believe their luck when he was replaced in 1963 by the epitome of upper-class languor, Sir Alec Douglas-Home. ${ }^{97}$

While Labour's approach was established before Wilson's election as leader, he made it his own in a series of speeches delivered between January and April 1964. ${ }^{98}$ These took as their theme the hope for a 'New Britain', which deliberately echoed the late President Kennedy's 'New Frontier' rhetoric. Wilson linked the economy's by now obvious decline (relative to the faster-growing French, German and Japanese economies) to the failure of the aristocratic Conservatives fully to utilise the talents of skilled manual and non-manual workers. As he suggested in 1963:

We need a shake-up in industry. There's still too much dead-wood too many directors sitting in boardrooms not because they can produce or sell, but because of their family background. To make industry dynamic we need vigorous young executives, scientists and sales experts chosen for their abilities - not their connections. ${ }^{99}$

Wilson's contention was that the Conservatives, by their very nature, were unable and unwilling to accomplish this task because theirs was a sectional party that identified with those who made money by speculation, not with those who earned it through work. A Labour government would use state planning to encourage industrial modernisation and thereby represent the 'thrusting ability, even iconoclasm' of grammar and comprehensive school pupils. It would also remove impediments to initiative endured by scientists, technicians, artisans and skilled workers. While the Conservatives allowed 'the spiv, the speculator, the take-over bidder, the tax evader, the land grabber' to prosper, Wilson 
promised Labour would promote 'the useful people', 'who earn money by useful service to the community'.

Only Labour, Wilson claimed, could liberate the energies of 'the useful people' and grant them the status they deserved. In so doing, Wilson was, as he admitted, 'making myself acceptable to the suburbs'. ${ }^{100}$ Indeed, such was the fear of being exclusively linked with 'traditional' working-class concerns that, during the 1964 campaign, a Labour official bemoaned a Daily Mirror 'shock issue' on housing because it associated the party with slums. ${ }^{101}$ This national emphasis was echoed in numerous local campaigns. In marginal Rugby, for example, Labour tried to appeal to young professionals by ensuring its candidate, a university lecturer, was "pushed as a young technocrat and the word DOCTOR was pushed on every occasion'. ${ }^{102}$ In marginal Berwick the candidate, John Mackintosh - coincidentally another university lecturer - also echoed Wilson's rhetoric by suggesting that the Conservatives could not appreciate ordinary people's problems because they 'live in country houses or Mayfair'. ${ }^{103}$

Complementing this focus, strategists tried to address what they took to be women's concerns by underlining domestic issues. In particular, one internal discussion paper asserted that prosperity was 'nowhere more deeply felt than in the home'. Moreover, it went on, 'home to the housewife, irrespective of whether she goes out to work or merely remains at home, is the focal point of her life'. In such women's lives a 'new house (Council or private), a family car, a television, an electric washer, cooker, and perhaps even a "frig", predominate'. Moreover, if a young housewife did not possess such things, she "aspires to do so as quickly as possible, and the "telly" is a daily reminder that life is not complete without them'. ${ }^{104}$ With that in mind, the party largely talked to women as consumers, which entailed a particular emphasis on the cost of living. As one delegate to the 1967 national conference of Labour women stated, 'all women were aggressive on the question of prices', in comparison with which other issues 'faded into insignificance'. ${ }^{105}$ Women's dependence on a male breadwinner was taken for granted: even one Labour woman defined the female electorate as consisting of 'the wives, the mothers, the widows, the sweethearts'. ${ }^{106}$ The party also assiduously appealed to them as mothers; one leaflet issued before the 1964 election, on which appeared a photograph of two children, simply urged women to 'Vote for Them'. Echoing the themes of 1959, they were exhorted to support Labour because it offered a 'new deal for the family' that focused on housing, education for children, improving pensions and provision for widows. By this time, however, there was a greater emphasis on the workplace: the promises to introduce equal pay and to improve nursery facilities for working mothers were both highlighted. ${ }^{107}$ 
Despite this frenetic activity, the substance of Labour's 1964 programme was strikingly similar to that of 1959. Only a few industries were to be nationalised; and the party's main aim was to promote expansion to the benefit of all, but most especially those in greatest need, who would gain from more welfare spending. Labour was asserted to be the party of all the people - as opposed to the sectional Conservatives. While suffused with a self-conscious modernity, Wilson's rhetoric betrayed a more fundamental continuity of approach. His reference to the 'useful people' could have been taken from speeches delivered by Herbert Morrison during the 1940s; indeed, the juxtaposition of 'unproductive' with 'productive' labour would have been familiar to any eighteenth-century radical. Wilson's emphasis on the need for hard work to increase productivity also had a 1940s tinge to it: implicitly at least it stood as a criticism of what many Labour members took to be a morally dubious affluent society in which easy money took precedence.

\section{Impact}

On 16 October 1964, Harold Wilson entered Downing Street as Prime Minister. While cause for celebration, Labour's victory was slender in terms of seats - it won a Commons majority of but four - and based on the share of votes cast, only 0.3 per cent higher and 10,000 votes fewer than in 1959.

The 1964 result was due more to the collapse of Conservative strength rather than any Labour recovery, the main beneficiary being the Liberal Party. The government had been unable to restore its authority after the Profumo scandal and Macmillan's failure to take Britain into the Common Market. Moreover, it was increasingly apparent that the relative performance of the British economy was unimpressive, as other countries were beginning to catch up. As a result, some suggest, there was a change in the national mood, from the optimism of the late 1950 s to a pervasive cynicism, which undermined support for the governing party. ${ }^{108}$ Yet the Conservatives still presided over rising standards of living after 1959, even if the rate of increase had slackened. On the eve of the campaign, 47 per cent of those asked by Gallup still considered the Conservatives the better able to maintain prosperity, as opposed to only 34 per cent who thought the task better entrusted to Labour. ${ }^{109}$ It appears that while Labour was seen to be more sympathetic to the needs of voters, it was still thought less economically competent than the Conservatives. ${ }^{10}$

Detailed evidence for the effectiveness of Labour's post-1959 strategy is limited but suggests strategists were not entirely successful in their efforts (see Table 3.1, p. 63). Labour increased its support among the middle classes but lost substantially among the 'very poor' and marginally 
so among the working class. Given that Labour's campaign concentrated on affluent voters, this was perhaps to be expected. More surprisingly, in terms of age, the party made no measurable gains in any category even among those in their twenties - while significant losses were registered among those over sixty-five years old, possibly because Labour did not stress pensions to the same degree as 1959. Similarly, with male voters the gains were marginal, while, despite its greater emphasis on women voters, the party had lost female support.

Even though it showed little immediate return for Labour's attempt to alter voters' perceptions, Conservative research discovered that by 1964 Labour was at least considered the more 'modern' of the two parties. ${ }^{11}$ More impressionistic still, during the campaign the Sun newspaper asked first-time voters to explain why they favoured a particular party. By no means all chose Labour, but a clear majority of letters published did: given the Sun's pro-Wilson inclination, this was no revelation. Even so, the reasons proffered revealed the extent to which Wilson's rhetoric made an impact on younger electors. One correspondent, for example, stated he would vote Labour as 'I believe a vast amount of talent and energy, especially among the young, will be released if we give Labour a chance to make a new Britain'. Another suggested that, under Wilson, 'the Britain of the future shall be a classless one, where all petty snobbisms of accent, dress, education will be defunct ... [it will be] a society which seeks to harness the talents of all in the best possible manner'. A third reader stated, 'I shall vote for the party of teachers and trained economists, the Labour Party; not the party of company directors and blimps'. ${ }^{112}$ At least in relation to that minority of young voters in the habit of writing letters to national newspapers, Labour left some sort of mark.

While Prime Minister, Wilson tried to build on the party's efforts after 1959 by showing that Labour was both economically responsible and able to live up to its spending promises. ${ }^{113}$ The result was what many considered Labour's landslide victory of 1966, a performance the junior minister Tony Benn thought indicated it was on the verge of becoming 'a truly national party'. ${ }^{14}$ Gallup's findings suggest there was some merit to this claim, for Labour's 1964 gains among the better-off classes were sustained, while support from the working class and poor rose markedly - as it did among both genders and all age groups (see Table 3.1, p. 63). Academic analysts now speculated that Labour was set to enjoy a prolonged period in office; in fact, because of the weight they gave parental influence over voter allegiance, some suggested that the Conservatives - lauded in 1959 as the 'normal' majority party were in danger of remaining out of office in perpetuity. ${ }^{115}$

Labour's re-election was, in contrast, taken very calmly at Transport House. The official report on the campaign was remarkably pessimistic 
but, as it turned out, prescient. The report identified the 'most significant feature' of the 1966 contest as the drop in turnout, from 77.1 per cent in 1964 to 75.8 per cent. Moreover, the report also found it worrying that the loss of two million Conservative voters since 1959 had been accompanied by only an 800,000 rise in Labour's poll. Given the party's failure to pick up a majority of Conservative losses, that many of the votes given to Liberals in 1964 went to Labour only because fewer Liberal candidates stood in 1966, and that twenty-five seats were won on a minority of the poll, the report firmly denied 1966 was anything like an 'overwhelming landslide'. ${ }^{116}$ Victory certainly did not mean Labour's organisational foundations were any less fragile than in 1959, for it was still unable to attract the participation of many women, the young or non-manual workers; existing activists remained too few in number, too ignorant of policy and procedure, and in need of more professional help. ${ }^{117}$ Despite appearances, Labour's 'landslide' victory did not mean anything had changed since 1959.

\section{Notes}

The place of publication is London unless otherwise specified.

1 Some of the material contained in this chapter has appeared in "White heat" and white collars: the evolution of "Wilsonism", in R. Coopey, S. Fielding and N. Tiratsoo (eds), The Wilson Governments, 1964-70 (1993).

2 Socialist Commentary, November 1963, pp. 3, 12; and Tribune, 4 October 1963.

3 D. E. Butler and R. Rose, The British General Election of 1959 (1960), pp. 196-201.

4 This account is based on P. M. Williams, Hugh Gaitskell (Oxford, 1982), pp. 299-313; B. Brivati, Hugh Gaitskell (1996), pp. 306-29; and Butler and Rose, 1959.

5 Labour Party Archive (LPA), NEC minutes, 28 October 1959; National Labour Women's Advisory Committee minutes, 5 November 1959 and 4 February 1960, Women's organisation and activities, p. 1; Labour Organiser, 38:499 (1959), pp. 211-12; London Metropolitan Archive (LMA), J. W. Raisin papers, Acc 2783/JWR/OA/2, R. Butterworth, Employment in the Northern Home Counties Region, conference for full-time agents, 26-28 April 1960.

6 Modern Records Centre (MRC), Labour Party East Midlands Region papers, MSS 9/3/79, reports on the 1959 campaign.

7 Bristol Record Office (BRO), Bristol South East CLP papers, 38423/48, H. Rogers, Parliamentary election, 8 October 1959 and 5 November 1959.

8 Bodleian Library, Conservative Party Archive (CPA), CCO 4/8/107, Northern Area, Review of the general election campaign, 1959, and South Eastern Area, Report on the general election, 1959.

9 CPA, CCO 500/9/9/1/2, General election 1959, The organisation and the future - notes for discussion, 12 December 1959.

10 East Midlands Region papers, MSS 9/3/79, East Midlands Regional Council 
Executive Committee minutes, 17 October 1959; CPA, CCO 4/8/107; J. Trenaman and D. McQuail, Television and the Political Image (1961).

11 R. Jenkins, The Labour Case (Harmondsworth, 1959), p. 135.

12 Labour Party, Housewives' Choice (1959).

13 Labour Party, The Britain We Want (1959), pp. 8-9.

14 Report of the Thirty-Sixth National Conference of Labour Women (1959), p. 20.

15 Butler and Rose, 1959, pp. 199-201; M. Abrams, R. Rose and R. Hinden, Must Labour Lose? (Harmondsworth, 1960).

16 British Library of Political and Economic Science (BLPES), Anthony Crosland papers, 13/23, paper for the 'Problems Ahead' conference, 1415 October 1950 . This was subsequently published as 'The transition from capitalism', in R. Crossman (ed.), New Fabian Essays (1952).

17 Socialist Commentary, November 1951, pp. 246-7.

18 LMA, London News, January 1956.

19 This account is based on T. Benn, Years of Hope. Diaries, Papers and Letters 1940-1962 (1994), pp. 317-19; T. Jones, Remaking the Labour Party (1996); Brivati, Gaitskell, pp. 330-48; Williams, Gaitskell, pp. 314-34.

20 Report of the Fifty-Eighth Annual Conference of the Labour Party (1959), pp. 105-14.

21 LPA, NEC Home Policy Sub-committee (HPSC) minutes, 11 January 1960; and Williams, Gaitskell, pp. 329-30.

22 J. M. Bochel, Activists in the Conservative and Labour parties. A study of ward secretaries in Manchester', MA thesis, University of Manchester (1965), pp. 140-2. More generally see Jones, Remaking, pp. 1-24.

23 Report of the Fifty-Fifth Annual Conference of the Labour Party (1956), p. 171; LPA, Morgan Phillips papers, GS/CMR/95, Secretary's Department to Eagles, 8 November 1957.

24 F. Bealey, J. Blondel and W. P. McCann, Constituency Politics (1965), pp. 2712, 283.

25 Report of the Fifty-Ninth Annual Conference of the Labour Party (1960), p. 12.

26 West Yorkshire Archive, City of Bradford Labour Party, Bradford East CLP minutes, 12 April 1960; MRC, Frank Cousins papers, MSS 282/TBN 13, notebook, 26 March 1960.

27 Crosland papers, 6/1, Crosland to Gaitskell, November 1960.

28 S. Fielding, 'Labourism in the 1940s', Twentieth Century British History, 3:2 (1992).

29 LPA, Romford, Hornchurch and Brentwood Labour Voice, mid-November 1951.

30 BLPES, Bedford CLP papers, 1/5A, GMC minutes, 12 February 1953; Warrington Local Studies Library, Warrington and District Labour News, 3 January 1953.

31 LPA, Bob Edwards papers, BE/EL/1955, Box 4, Personal files, General election 1955.

32 LPA, Judith Hart papers, Section 1, File 1 (ii), speech to selection meeting, Lanark, 1957.

33 LPA, Barons Court Citizen, July 1959; Report of the Thirty-Sixth National Conference of Labour Women (1959), pp. 8, 10-11, 19.

34 BRO, Labour Party South West Region papers, 10/3, G. Care, application for a Laski Memorial Scholarship, April 1963.

35 House of Lords Record Office (HLRO), Reginald Sorenson papers, Hist. Coll. 102/230, A backbencher's pilgrimage, 1968, pp. 245, 403.

36 BLPES, North Kensington CLP papers, North Kensington Labour Questionmaster, April 1955.

37 G. McClymont, “A squalid raffle”? Labour, affluence and the introduction 
of Premium Bonds, 1956', paper presented to the conference 'Affluent Britain?', Bristol University, May 2002.

38 London News, June 1958.

39 L. Manning, A Life for Education (1970), pp. 193, 195.

40 Bedford CLP papers, 1/12, GMC minutes, 8 June 1967.

41 Focus, 2 (1955), pp. 9-10.

42 Tribune, 28 December 1951.

43 J. Freeman, 'Labour's decline', Focus, 2 (1955), pp. 12-13.

44 Fifty-Eighth Annual Conference of Labour, p. 127; Baron's Court Citizen, November-December 1959.

45 National Library of Wales (NLW), Ron Evans papers, 5, Evans to Machray, 22 November 1959.

46 H. Jenkins, R. Lewis. G. Southgate and W. Wolfgang, 'The red sixties', Victory for Socialism Pamphlet (1957), pp. 7, 12.

47 S. Fielding, “'But westward, look, the land is bright!” Labour's revisionists and the imagining of America, c. 1945-64', in J. Hollowell (ed.), TwentiethCentury Anglo-American Relations (2001).

48 BLPES, Edgar Simpkins papers, MISC 0502, Folkestone 1959 general election scrapbook.

49 Forward, 28 October 1955.

50 R. H. S. Crossman, Planning for Freedom (1965), pp. 86-112.

51 Labour Woman, 48:5 (1960), p. 59; Tribune, 16 October 1959.

52 Fifty-Eighth Annual Conference of Labour, p. 122.

53 South West Region papers, 10/3, Cormack application.

54 MRC, Warwick and Leamington Spa CLP papers, MSS 133, Box 1, Annual report 1959.

55 Labour Woman, 47:9 (1959), p. 122.

56 South West Region papers, 38423/43, J. H. Knight, General election, 1959 report.

57 P. Shore, The Real Nature of Conservatism (1952), pp. 26-9.

58 Fifty-Eighth Annual Conference of Labour, pp. 126-7.

59 MRC, Maurice Edelman papers, MSS 125/3/Temp 5, Report by Maurice Edelman MP for the year ended 31 August 1960.

60 This account is based on C. A. R. Crosland, The Conservative Enemy (1962), pp. 116, 144-6, 149-50, 152, 157, 161-2. See also J. Pearson and G. Turner, The Persuasion Industry (1965) and R. Rose, Influencing Voters (1967).

61 HLRO, Charles Pannell papers, Hist. Coll. 124/ D1, Leeds Weekly Citizen, 20 November and 11 December 1959.

62 NEC minutes, 28 October 1959; HPSC minutes, 11 January 1960.

63 P. Crane, 'What's in a party image?', Political Quarterly, 30:3 (1959), pp. 233-5.

64 C. Rowland, 'Labour publicity', Political Quarterly, $31: 3$ (1960), pp. 349-50; and Labour Organiser, 39:458 (1960), pp. 147-8.

65 Labour Organiser, 42:488 (1963), p. 32.

66 Labour Organiser, 39:459 (1960), pp. 174-6; 39:462 (1960), pp. 225-6; and 41:486 (1962), pp. 225-6.

67 Labour Organiser, 42:489 (1963), p. 57.

68 M. Abrams, 'Opinion polls and party propaganda', Public Opinion Quarterly, 28:1 (1964), p. 16.

69 NEC minutes, 13 July 1960, The state of the party, Sec. No. 104, pp. 11-14.

70 K. Young, 'Orpington and the "Liberal revival", in C. Cook and J. Ramsden (eds), By-elections in British Politics (1973).

71 Labour Organiser, 40:467 (1961), p. 95. 
72 Labour Organiser, 40:463 (1961), p. 5; and 40:468 (1961), p. 109.

73 BLPES, Hugh Jenkins papers, 6/46, Trade unions and the middle classes, c. 1950 .

74 Labour Organiser, 40:465 (1961), pp. 54.

75 NEC, Organisation Sub-committee (OSC) minutes, 14 February 1961, Meeting of representatives of non-manual workers' unions, NAD/21/2/61, and L. Williams, Preliminary meeting of non-manual workers' unions to be held on Thursday 9 February 1961; and 19 September 1961, Non-manual workers' unions and the Labour party, NAD/76/8/61; Labour Organiser, 40:467 (1961), pp. 83-5; Tribune, 23 October 1959; Labour Woman, 50:7 (1962), pp. 4-5.

76 HPSC minutes, 9 July 1962, Non-manual workers and the Labour party, RD 300.

77 Bristol South East CLP papers, 39035/133, H. E. Rogers, Parliamentary by-election, 4 May 1961, 29 May 1961.

78 T. Benn, Out of the Wilderness. Diaries, 1963-67 (1987), pp. 136, 213.

79 Bristol South East CLP papers, 39035/47, GMC minutes, passim and 4 November 1965; 39035/21, Young Socialist minutes, 1 November 1960.

80 MRC, Socialist Vanguard Group papers, MSS 173, Box 5, Penny Farthing file, Benn to Hinden, 7 January 1965.

81 OSC minutes, 17 July 1962, The case against a smaller individual membership contribution and an associate membership, NAD/72/7/62.

82 OSC minutes, 18 September 1963; Benn, Wilderness, p. 65; South West Region papers, 38423/48, Benn to Rees, 9 December 1963.

83 OSC minutes, 18 November 1964, Support for the Labour Party, NAD/70/ $11 / 64$.

84 Bristol South East CLP papers, 39035/21, GMC minutes, 12 December 1963 and 6 February 1964.

85 Bristol South East CLP papers, 39035/146, GMC minutes, 3 December 1964; New Bristol Group, Output 1962/3 (1963), p. 2.

86 This account is based on LPA, Campaign Sub-committee (CSC) minutes, 22 January, 19 July and 19 December 1962, and 11 March and 13 May 1963; Labour Party, 'Let's Go' Campaign Guide (1963); Socialist Commentary, July 1963, pp. 10-12; Labour Organiser, 42:493 (1963), pp. 130-2; and New Society, 6 June 1963.

87 Daily Mirror, 21 May 1963.

88 Pannell papers, Hist. Coll. 124/ D3, Leeds Weekly Citizen, 27 April 1962 and 31 May 1963.

89 Labour Organiser, 42:491 (1963), p. 90; 42:492 (1963), pp. 107-8; 42:496 (1963), pp. 186-8 and 195-6; 43:499 (1964), p. 9; and Labour Woman, 51:6 (1963), p. 7.

90 Forward, 22 January 1960; Labour Party, Science and the Future of Britain (1961); A. Howard, Crossman. The Pursuit of Power (1990), p. 248.

91 J. Morgan (ed.), The Backbench Diaries of Richard Crossman (1981), pp. 860-1.

92 LPA, Publicity and Political Education Sub-committee minutes, 20 June 1960.

93 NEC minutes, 27 July 1960.

94 Report of the Fifty-Ninth Annual Conference of the Labour Party (1960), pp. 133$4,149$.

95 Report of the Sixtieth Annual Conference of the Labour Party (1961), pp. 129-30.

96 Abrams, 'Opinion polls', p. 17.

97 Benn, Wilderness, p. 70.

98 Unless otherwise stated, references for the next three paragraphs are taken from H. Wilson, The New Britain (Harmondsworth, 1964). 
99 National Union of Sheet Metal Workers and Coppersmiths Quarterly Journal, July 1963, pp. 25-6.

100 A. Watkins, 'Labour in power', in G. Kaufman (ed.), The Left (1966), p. 176.

101 R. West, 'Campaign journal', Encounter, December 1964, p. 19.

102 MRC, Rugby CLP papers, MSS 10/3/7/39/1, R. Page, General election 1964.

103 National Library of Scotland, John P. Mackintosh papers, Dep 323/70, Notes for Dunbar meeting, 30 January 1964.

104 Calderdale Archives, Halifax CLP papers, TU: 28/16, Miscellaneous correspondence, 1959-60, Yorkshire Regional Office of the Labour Party, Report on Women's Organisation for consideration at special meetings of Women's Advisory Councils with the Chief Woman Officer on 13, 14 and 15 January 1960, January 1960.

105 Report of the Forty-Fourth National Conference of Labour Women (1967), p. 43.

106 Report of the Forty-First National Conference of Labour Women (1964), pp. 11, 14.

107 Labour Party, Let's Have a Party That Will Get Things Done (1963), and Vote for Them (1964).

108 D. Butler and A. King, The British General Election of 1964 (1965), pp. 304, 97 and 145 .

109 G. H. Gallup, The Gallup International Public Opinion Polls. Great Britain, 1937-75. Volume I (New York, 1976), p. 768.

110 CSC minutes, 13 May 1963.

111 CPA, 180/11/2/1, Thomson Organisation, 'Voters and the 1964 general election', March 1964.

112 Sun, 30 September, 2 and 6 October 1964.

113 For this period, see in particular E. Short, Whip to Wilson (1989).

114 Benn, Wilderness, p. 399.

115 Butler and Rose, 1959, p. 197; D. Butler and A. King, The British General Election of 1966 (1966), pp. ix and 267-9.

116 HPSC minutes, 11 July 1966, The 1966 general election, re 20 July 1966.

117 NEC minutes, SEC/22/7/66, 26 October 1966, Party organisation. 